\title{
Hyper IgM Syndrome Associated with Defective CD40-mediated B Cell Activation
}

\author{
Mary Ellen Conley, * Mark Larché, ${ }^{*}$ Vincent R. Bonagura, ${ }^{5}$ Alexander R. Lawton III," Rebecca H. Buckley,' Shu Man Fu, * * \\ Elaine Coustan-Smith, ${ }^{*}$ Henry G. Herrod, ${ }^{*}$ and Dario Campana ${ }^{\ddagger *}$ \\ * Department of Pediatrics, University of Tennessee College of Medicine, Memphis, Tennessee; ${ }^{\ddagger}$ Departments of Immunology and \\ Hematology/Oncology, St. Jude Children's Research Hospital, Memphis, Tennessee; ${ }^{8}$ Division of Allergy and Immunology, Schneider \\ Children's Hospital, Long Island, New York; "Department of Pediatrics, Vanderbilt University School of Medicine, Nashville, Tennessee; \\ 'Department of Pediatrics, Duke University School of Medicine, Durham, North Carolina; and **Department of Medicine, University of \\ Virginia School of Medicine, Charlottesville, Virginia
}

\begin{abstract}
Recent studies show that most patients with $\mathrm{X}$-linked hyper IgM syndrome have defects in the gene for CD40 ligand. We evaluated 17 unrelated males suspected of having $X$ linked hyper IgM syndrome. Activated T cells from 13 of the 17 patients failed to bind a soluble CD40 construct. In these patients, the sequence of CD40 ligand demonstrated mutations. By contrast, $T$ cells from the remaining four patients exhibited normal binding to the CD40 construct. Sequencing of the cDNA for CD40 ligand from these patients did not show mutations. The possibility that hyper IgM syndrome in these four patients was due to abnormalities in the $B$ cell response to CD40-mediated signals was examined. Peripheral blood lymphocytes were stimulated with anti-CD40 alone, IL4 alone or anti-CD40 plus IL4. In comparison with $B$ cells from controls or patients with hyper IgM syndrome and mutant CD40 ligand, B cells from the patients with hyper IgM syndrome and normal CD40 ligand were defective in their ability to secrete IgE $(P<0.02)$ or express activation markers, $\mathrm{CD} 25$ and $\mathrm{CD23}(P<0.02)$ in response to stimulation with anti-CD40. The failure of these $B$ cells to respond to CD40-mediated activation could not be attributed to a generalized deficiency in $B$ cell activation because $\mathrm{IL4}$ induced normal up-regulation of $\mathrm{CD23}$ and CD25 expression. These findings indicate that hyper IgM syndrome may result from defects in expression of CD40 ligand by activated $T$ cells or defects in CD40-mediated signal transduction in B cells. ( $J$. Clin. Invest. 1994. 94:14041409.) Key words: B lymphocytes $-X$ chromosome • agammaglobulinemia • immunophenotyping • IgE
\end{abstract}

\section{Introduction}

Hyper IgM syndrome is a term used to describe a heterogeneous group of disorders characterized by normal or elevated concentrations of serum IgM but markedly decreased IgG, IgA and IgE (1). Autosomal recessive, autosomal dominant, acquired,

Address correspondence to Mary Ellen Conley, M.D., St. Jude Children's Research Hospital, 332 N. Lauderdale, Memphis, TN 38105. Received for publication 2 May 1994 and in revised form 30 June 1994.

J. Clin. Invest.

(c) The American Society for Clinical Investigation, Inc.

0021-9738/94/10/1404/06 \$2.00

Volume 94, October 1994, 1404-1409 and $\mathrm{X}$-linked forms have been described (2-6). Although patients with X-linked hyper IgM syndrome have an early onset of infections and an increased incidence of neutropenia and opportunistic infections $(2,3)$, it is not always possible to distinguish the various forms of hyper IgM syndrome based on laboratory or clinical findings. Difficulties in making an accurate diagnosis are compounded by the fact that, as in all X-linked disorders that are lethal without medical intervention (7), a third to half of the patients with X-linked hyper IgM syndrome will have no family history of immunodeficiency because they represent the first manifestation in their family of a new mutation.

Several laboratories have recently demonstrated that the Xlinked form of hyper IgM syndrome is caused by mutations in the gene for CD40 ligand (8-12). CD40 ligand, which is also referred to as gp 39 , is a Type II transmembrane protein with homology to TNF and nerve growth factor $(13,14)$. It is expressed on the surface of activated $T$ cells where it functions as a growth and differentiation factor, with particular specificity for B cells $(15,16)$. Patients with X-linked hyper IgM syndrome have shown point mutations resulting in amino acid substitutions or altered splice sites and insertions or deletions in the gene for CD40 ligand (8-12).

CD40 is a $B$ cell surface antigen with homology to a family of growth factor receptors including CD27, CD30, and Fas, as well as TNF receptor and nerve growth factor receptor (17, 18). Stimulation of $B$ cells with CD40 ligand or antibodies to CD40 results in expression of B cell activation markers, short and long term proliferation, protection from apoptosis, and in the presence of cytokines, isotype switching (19-22).

To determine whether there were clinical or laboratory features that would distinguish patients with $\mathrm{X}$-linked hyper IgM syndrome from those with other forms of the disease and to explore the possibility that some patients with hyper IgM syndrome might have defects in response to CD40 mediated B cell activation, we evaluated a series of 17 unrelated males suspected of having X-linked hyper IgM syndrome. We identified four patients with normal expression of CD40 ligand but defective $B$ cell responses to activation mediated by CD40 stimulation. One of these patients had a family history of disease compatible with X-linked inheritance.

\section{Methods}

Patients. The patients included in this study received their medical care at 11 medical centers throughout the United States. Inclusion criteria were: $(a)$ males; $(b)$ onset of recurrent infections before two years of age; (c) serum IgG and IgA more than two standard deviations below the normal mean for age; $(d)$ normal numbers of peripheral blood B 
cells. Elevated concentrations of serum IgM were not required. All of the patients were between 18 mos and $24 \mathrm{yr}$ of age at the time of the study. Some clinical or laboratory records from 10 affected male relatives were available for study. Routine clinical laboratory studies were performed at the referring institution. Not all studies were available on all patients.

Cell activation and flow cytometry. Mononuclear cells, obtained by centrifugation on a density gradient (Lymphoprep, Nycomed, Oslo) were cultured at $1.5 \times 10^{6}$ cells $/ \mathrm{ml}$ in RPMI- 1640 with $10 \%$ fetal calf serum and $2 \mathrm{mM}$ L-glutamine in 24-well microtiter plates (Costar Corp., Cambridge, MA). To analyze CD40 ligand expression and stimulated CD40 expression, cells were cultured with phorbol-12-myristate-13acetate (TPA) ${ }^{1}$ and ionomycin as described (16). Stimulated and unstimulated cells were harvested at $16-20 \mathrm{~h}$ and washed twice in phosphate-buffered saline containing $0.2 \%$ bovine serum albumin and $0.2 \%$ sodium azide (PBSA). For CD40 ligand staining, cells were incubated for $10 \mathrm{~min}$ at room temperature with a recombinant construct consisting of the extracellular domain of CD40 and the Fc portion of human IgM (16) or with a control human IgM myeloma protein. Cells were washed twice with PBSA and then stained with goat anti-human IgM labeled with phycoerythrin (Southern Biotechnology Associates, Birmingham, $\mathrm{AL}$ ), fluorescein isothiocyanate conjugated anti-CD3 (Becton-Dickinson, San Jose, CA) and peridin chlorophyll protein (PerCP)-labeled anti-CD8. For CD40 staining, cells were incubated as above with a 1/ 10,000 dilution of ascites from 626.1 , a murine IgG1 monoclonal antibody to $\mathrm{CD} 40(22) \sim 0.25 \mu \mathrm{g} / \mathrm{ml}$ final concentration) and an unlabeled murine IgM monoclonal antibody to CD19 (Bly3, kind gift of Dr. S. Poppema, Edmonton, Alberta). In control tubes, non-reactive isotypematched reagents were used. Washed cells were incubated with fluorescein isothiocyanate-labeled goat anti-mouse IgG and phycoerythrinlabeled anti-mouse IgM (Southern Biotechnology Associates).

To investigate B cell activation via the CD40 molecule, cells prepared as described above were cultured without stimulation, with 100 $\mathrm{U} / \mathrm{ml}$ of IL4 (Genzyme Corp., Cambridge, MA), with a 1/10,000 dilution of monoclonal anti-CD40 or with both IL 4 and anti-CD40. To crosslink CD40, unlabeled goat anti-mouse IgG at $0.25 \mathrm{mg} / \mathrm{ml}$ (Jackson Immunoresearch Labs, West Grove, PA) was added to all cultures, including those without anti-CD40. After harvest and washes as described above, cells were incubated with mouse serum to block the goat anti-mouse IgG and then stained with phycoerythrin labeled anti-CD19 and fluorescein isothiocyanate-labeled anti-CD23 (Amac, Westbrook, ME) or anti-CD25 (Dako Corp., Carpenteria, CA). Isotype matched non reactive immunoglobulins conjugated to the corresponding fluorochromes were used as controls. After staining, all cells were washed twice in PBSA and fixed in $0.5 \%$ paraformaldehyde.

Immunophenotype was analyzed with a FACScan flow cytometer, using the Lysis II software (Becton Dickinson). At least 10,000 lymphocytes were studied in each sample. CD40 ligand expression was evaluated on CD3+, CD8 - cells; CD40, CD23, and CD25 staining was selectively studied on CD19+ B lymphocytes.

Sequencing of CD40 ligand cDNA. Peripheral blood lymphocytes were cultured for 16 to $18 \mathrm{~h}$ at $10^{6}$ cells/ml in RPMI 1640 with $15 \%$ fetal calf serum and a 1/1,000 dilution of phytohemagglutinin. RNA extracted from these cells was used as a template for CDNA which was amplified by PCR as described (8) except that EcoRI and XbaI sites were added to the ends of the primers. The two overlapping PCR products were digested with EcoRI and XbaI, ligated into pUC 19 at these sites and sequenced using universal M13 primers or oligomers derived from CD40 ligand CDNA sequence.

In vitro production of IgE. Peripheral blood lymphocytes from patients and controls were cultured in parallel at $5 \times 10^{5}$ cells $/ \mathrm{ml}$ for 10 $\mathrm{d}$ in supplemented Iscove's modified Dulbecco's medium, as described by Claasen et al. (23) without additional stimulation, with $150 \mathrm{U} / \mathrm{ml}$

1. Abbreviations used in this paper: PBSA, phosphate buffered saline containing $0.2 \%$ bovine serum albumin and $0.2 \%$ sodium azide; TPA, phorbol-12-myristate-13-acetate. of IL4 (Amgen Biologicals), with a 1/10,000 dilution of anti-CD40 monoclonal antibody or with both IL 4 and anti-CD40. Supernatants from duplicate cultures were analyzed using an IgE specific ELISA with a sensitivity of $100 \mathrm{pg} / \mathrm{ml}$.

\section{Results}

Expression of CD40 ligand on activated $T$ cells. Preliminary studies have suggested that activated $\mathrm{T}$ cells from all patients with X-linked hyper IgM syndrome fail to bind recombinant constructs consisting of the CD40 receptor and the Fc portion of an immunoglobulin molecule (8-11). To extend this observation, peripheral blood lymphocytes from 17 unrelated males suspected of having X-linked hyper IgM syndrome were cultured for 16-19 h with calcium ionophore and TPA. One aliquot of activated cells was incubated with a recombinant construct consisting of the extracellular portion of CD40 and the Fc portion of IgM and then stained with flurochrome conjugated antiIgM. Another aliquot was stained with antibody to the IL2 receptor alpha chain (CD25) to document normal T cell activation. Although activated $\mathrm{T}$ cells from all of the patients demonstrated expression of the IL2 receptor, cells from 13 of the 17 patients failed to bind the CD40 construct (CD40 ligand negative patients) (Fig. 1). Activated $\mathrm{T}$ cells from the remaining four patients (CD40 ligand positive patients) did not differ from controls in the proportion of cells binding to the construct $(61.8 \pm 8.0 \%$ in the patients vs $64.6 \pm 13.6 \%$ in controls ) or in the intensity of binding as measured by mean fluorescence intensity (89.1 \pm 57.9 in patients vs $82.0 \pm 36.4$ in controls).

Sequencing of CD40 ligand. One could postulate that some mutations in the gene for CD40 ligand might permit normal binding to CD40 but with abnormal functional consequences. To explore this possibility, we sequenced the cDNA for CD40 ligand in all four patients demonstrating normal binding to the CD40 construct. The sequence was identical to that of the normal controls, confirming that hyper IgM syndrome in these four patients was not due to defects in CD40 ligand.

Expression of CD40 on B cells. To determine whether hyper IgM syndrome in the four patients with normal CD40 ligand was due to defects at other points in the CD40 ligand-CD40 axis, we evaluated $B$ cell surface expression of CD40 and the ability of anti-CD40 antibodies to transmit an activation or differentiation signal to B cells from affected patients. As defined by entry criteria for the study, the proportion of peripheral blood $B$ cells, as determined by surface expression of CD19, was normal in both the CD40 ligand negative patients $(9.7 \pm 4.2 \%)$ and CD40 ligand positive patients $(7.4 \pm 1.6 \%)$.

Indirect immunofluorescence staining of $B$ cells from the CD40 ligand positive patients with monoclonal antibody to CD40 was normal in all four patients. All CD19+ B cells were positive for CD40 with a mean fluorescence intensity that was similar to that seen in controls $(84.8 \pm 19.8$ in controls vs $68.0 \pm 2.5$ in patients, $P$ NS $)$. After stimulation with ionomycin and TPA, CD40 expression on B cells from normal controls and CD40 ligand positive patients decreased dramatically. Mean fluorescence intensity fell to $14.0 \pm 6.5$ in controls and $8.3 \pm 4.2$ in CD40 ligand positive patients $(P<0.001$ compared to prestimulation for both controls and CD40 ligand positive patients). Decreased expression of CD40 on B cells, which occurred concurrently with up-regulation of CD40 ligand on activated $T$ cells, was not seen in co-cultures of $B$ and $T$ cells separated by a microporous membrane or in cultures incubated 

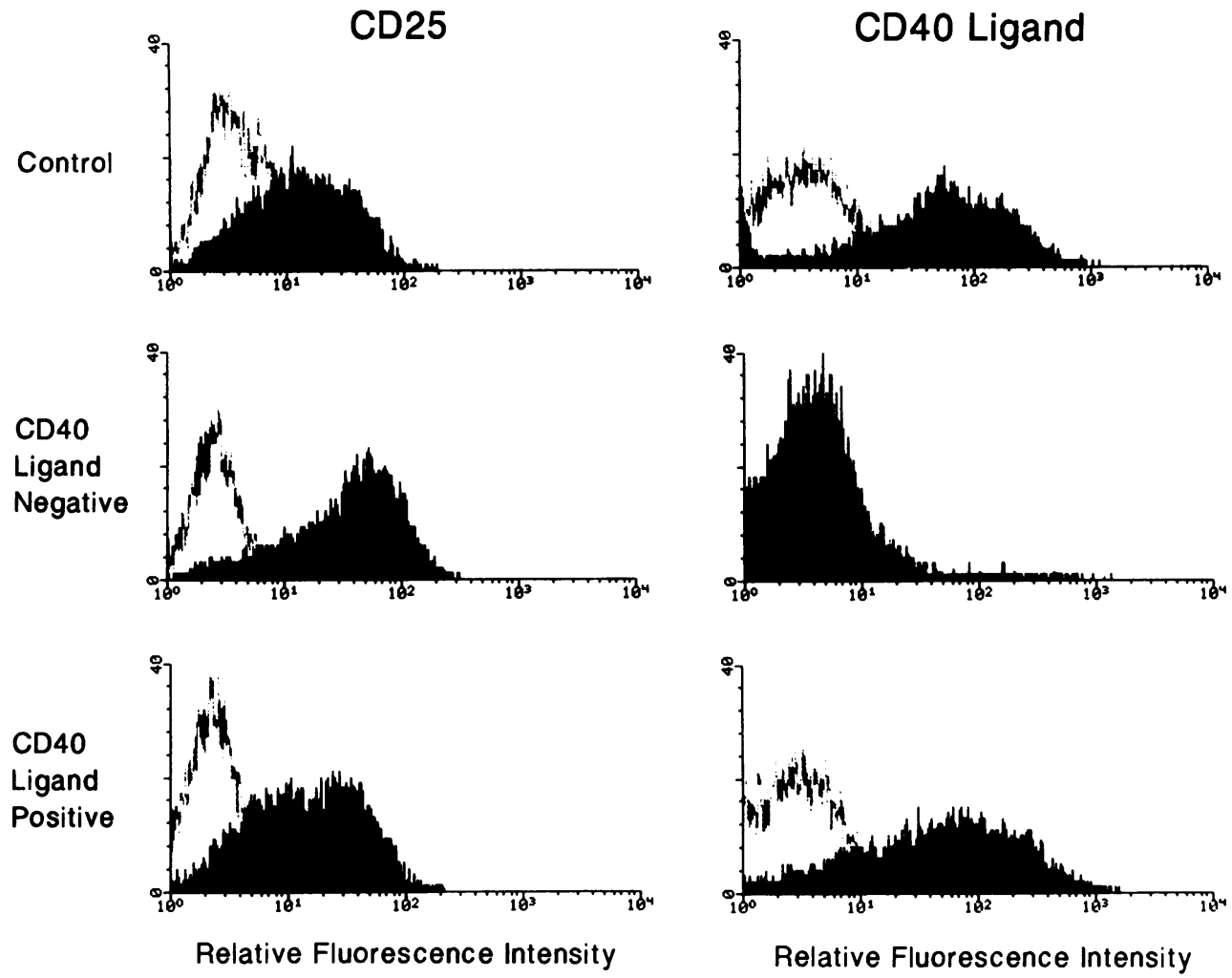

Figure 1. Expression of CD40 ligand on activated T cells. Peripheral blood lymphocytes from healthy controls and patients suspected of having $\mathrm{X}$-linked hyper IgM syndrome were stimulated for 16 to $20 \mathrm{~h}$ with TPA and ionomycin. An aliquot of cells was stained with antibody to CD25 to document normal $\mathrm{T}$ cell activation. A separate aliquot was incubated with a recombinant construct consisting of the extracellular domain of CD40 and the Fc portion of human IgM. These cells were then washed and stained with fluorochrome tagged antihuman IgM. Both aliquots were stained with antibodies to $\mathrm{CD} 3$ and CD8 with contrasting fluorochromes. At least 10,000 cells that were $\mathrm{CD} 3$ + and $\mathrm{CD} 8$ - were analyzed for expression of $\mathrm{CD} 25$ (left) or CD40 ligand (right). The relative fluorescence intensity is shown on the $x$ axis and the relative cell number is shown on the $y$ axis; staining with an isotype control is shown as an open curve, CD25 or CD40 ligand staining is shown as the filled curve. The 17

patients suspected of having X-linked hyper IgM syndrome could be divided into two groups: cells from 13 patients failed to bind the CD40 construct (CD40 ligand negative patients, shown in the middle panels); however, cells from the remaining four patients demonstrated normal binding to the construct (CD40 ligand positive patients, shown in the bottom panels).

with soluble CD40 (data not shown), suggesting that CD40 down-regulation required $\mathrm{T}$ and $\mathrm{B}$ cell contact and CD40 ligand-CD40 interaction.

B cells from patients with CD40 ligand negative hyper IgM syndrome demonstrated normal expression of CD40; however, in cultures from these patients, CD40 expression on B cells increased after ionomycin and TPA stimulation (pre-stimulation $82.6 \pm 17.3$ vs. post-stimulation $149.6 \pm 36.1$ ), supporting a role for CD40 ligand in the down-regulation of CD40 expression.

In vitro IgE production. The ability of $\mathrm{B}$ cells from the four CD40 ligand positive hyper IgM patients to respond to signals delivered through CD40 was evaluated in an in vitro IgE production assay. Peripheral blood lymphocytes from either normal controls or patients with hyper IgM syndrome were cultured for $10 \mathrm{~d}$ without stimulation, with IL4 alone, with anti-CD40 alone, or with IL4 plus antibody to CD40. Less than $500 \mathrm{pg} /$ $\mathrm{ml}$ of IgE was produced by cells from controls or patients cultured without stimulation or by cells cultured with antibody to CD40 alone. When cultured with IL4 alone, cells from controls produced a mean of $52,000 \mathrm{pg} / \mathrm{ml}$ of IgE (Table I). When anti-CD40 was added to IL4 stimulated cultures, the amount of IgE secreted increased to a mean of $367,000 \mathrm{pg} / \mathrm{ml}$. Although lymphocytes from patients with CD40 ligand negative hyper IgM syndrome did not secrete IgE in response to stimulation with IL4 alone $(<500 \mathrm{pg} / \mathrm{ml})$, they did respond to IL4 plus anti-CD40 $(67,000 \mathrm{pg} / \mathrm{ml})$. By contrast, lymphocytes from the patients with CD40 ligand positive hyper IgM syndrome produced less than $5 \%$ of the amount of IgE secreted by controls in cultures stimulated either with IL4 alone $(P<0.02)$ or with IL4 plus antibody to CD40 ligand $(P<0.01)$.

Expression of $C D 25$ and $C D 23$ in response to $C D 40$ mediated stimulation. The failure of B cells from patients with CD40 ligand positive hyper IgM syndrome to secrete IgE could be due to defects in response to either IL4 or CD40 stimulation. We examined this question in more detail in three patients from two unrelated families. Peripheral blood lymphocytes were cultured for 16-20 h with anti-CD40 alone, IL4 alone or antiCD40 plus IL4. Co expression of CD19 and the B cell activation markers CD25 and CD23 was then analyzed by immunofluorescent staining. B cells from controls and CD40 ligand negative patients demonstrated a $50-100 \%$ increase in expression of both CD25 and CD23 in response to stimulation with anti-CD40 alone (Fig. 2). However, expression of CD25 and CD23 on B cells was not altered by anti-CD40 stimulation in cultures from patients with CD40 ligand positive hyper IgM syndrome. The failure of B cells to respond to CD40-mediated activation in these patients was not due to an intrinsic defect in $\mathrm{B}$ cell activation as demonstrated by the $1,000 \%$ increase in CD23 expression and $200-300 \%$ increase in CD25 expression in parallel cultures incubated with IL4. The increase in CD23 expression exceeded that seen in cultures from normal controls or CD40 ligand negative patients $(P<0.02)$.

Addition of anti-CD40 to IL4-stimulated cultures from CD40 ligand positive patients did not increase the CD25 expression achieved with IL 4 alone. By contrast, anti-CD40 markedly enhanced CD25 expression in IL 4 stimulated cultures from con- 
Table I. In Vitro IgE Production by Peripheral Blood Lymphocytes from Patients with Hyper IgM Syndrome

\begin{tabular}{|c|c|c|c|c|c|}
\hline & \multirow[b]{2}{*}{$\begin{array}{l}\text { Anti-CD40 alone } \\
\text { IgE in } \mathrm{pg} / \mathrm{ml}\end{array}$} & \multicolumn{2}{|c|}{ IL4 alone } & \multicolumn{2}{|c|}{$\mathrm{IL} 4$ + anti-CD40 } \\
\hline & & IgE in $\mathrm{pg} / \mathrm{ml}$ & $\begin{array}{l}\text { Percent of } \\
\text { control }\end{array}$ & IgE in $\mathrm{pg} / \mathrm{ml}$ & $\begin{array}{c}\text { Percent of } \\
\text { control }\end{array}$ \\
\hline \multicolumn{6}{|l|}{ CD40 ligand positive patients } \\
\hline Patient 1 & $<100$ & $<100$ & $<0.1 \%$ & 880 & $0.2 \%$ \\
\hline Patient 2 & $<100$ & $<100$ & $<0.1 \%$ & $<100$ & $<0.1 \%$ \\
\hline Patient 3 & $<100$ & 319 & $0.4 \%$ & 9,685 & $2.0 \%$ \\
\hline Patient 4 & $<100$ & 124 & $0.3 \%$ & 12,254 & $1.0 \%$ \\
\hline CD40 ligand negative patients (3) & $<100$ & $\begin{array}{c}259 \\
(<100-475)\end{array}$ & $1.6 \%$ & $\begin{array}{c}67,074 \\
(32,000-110,000)\end{array}$ & $47 \%$ \\
\hline Healthy controls (8) & $\begin{array}{c}156 \\
(<100-563)\end{array}$ & $\begin{array}{c}52,067 \\
(12,392-101,661)\end{array}$ & & $\begin{array}{c}366,994 \\
(134,527-1,147,400)\end{array}$ & \\
\hline
\end{tabular}

Peripheral blood lymphocytes from patients and controls were cultured for $10 \mathrm{~d}$ with $150 \mathrm{U} / \mathrm{ml}$ of IL4, with 626.1 , a monoclonal anti-CD40 antibody, or with both IL4 and anti-CD40. Supernatants were assayed by ELISA for IgE concentration. The results were expressed as $\mathrm{pg} / \mathrm{ml}$ of IgE and percent of the control that was studied in parallel with the patient sample.

trols $(P<0.05)$ and CD40 ligand negative patients. Anti-CD40 in the presence of IL4 did induce an increase in CD23 expression in CD40 ligand positive cultures; however, this increase was less impressive than that seen in cultures from controls or CD40 ligand negative patients. In summary, B cells from CD40 ligand positive patients with hyper IgM syndrome showed a markedly defective response to CD40 mediated activation which was accompanied by hyper responsiveness to IL 4 .

Clinical characteristics of CD40 ligand negative and CD40 ligand positive patients. To determine whether there were clinical or laboratory findings that would distinguish patients with hyper IgM syndrome who had defects in CD40 ligand from
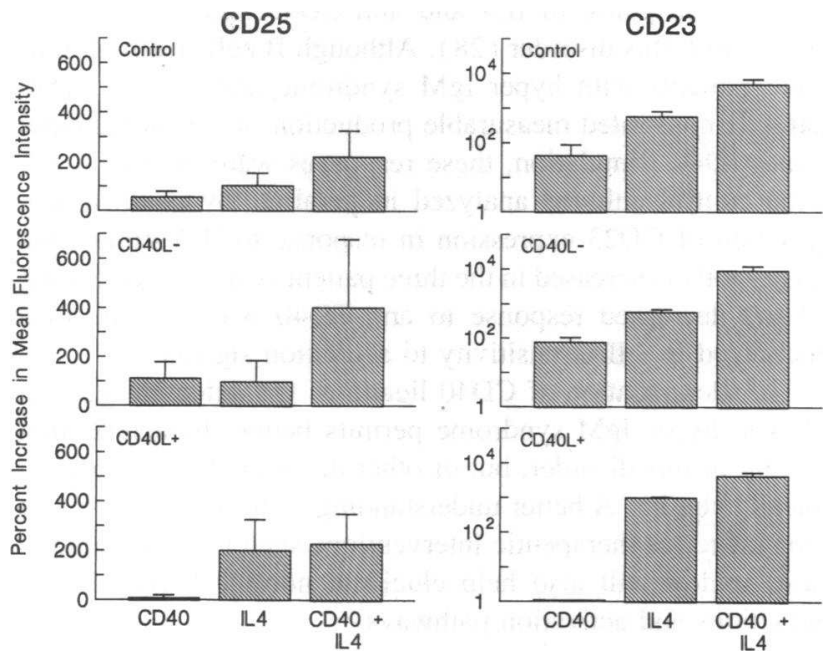

Figure 2. Expression of CD25 and CD23 on activated B cells. Peripheral blood lymphocytes from healthy controls, from CD40 ligand negative patients ( $C D 40 L-)$, and from CD40 ligand positive patients (CD4OL+) were cultured for $16-20 \mathrm{~h}$ without stimulation, with anti-CD40, with IL-4, or with anti-CD40 plus IL4. Washed cells were stained with fluorochrome tagged anti-CD25 (left) or anti-CD23 (right). The bars represent the percent increase in mean fluorescence intensity in expression of these antigens on activated cells compared to cells cultured without stimulation. A linear scale is used to show increase in CD25 expression whereas a log scale is used for CD23. those with normal CD40 ligand, we examined the past medical records of the patients and their similarly affected male relatives. Of the 13 patients with defects in CD40 ligand, four had affected maternal uncles or cousins and 3 had affected brothers, the remaining six patients were considered sporadic cases. One of the four patients with normal CD40 ligand (Patient 4) had affected relatives. This patient, who had hypohidrotic ectodermal dysplasia as well as hyper IgM syndrome, had a maternal half brother with both hypohidrotic ectodermal dysplasia and hyper IgM syndrome. He also had a maternal uncle who died of meningitis at one month of age.

The concentrations of serum immunoglobulins in the patients with normal expression of CD40 ligand were not markedly different from those of patients with defects in CD40 ligand (Table II). Although all patients had decreased serum IgA, concentrations of IgA $>10 \mathrm{mg} / \mathrm{dl}$ were detected at some time in 3 of the 5 patients with normal CD40 ligand and in 9 of the 15 patients with defects in CD40 ligand. Opportunistic infections were more common in the patients with defects in CD40

Table II. Serum Immunoglobulin Concentrations in Patients with Hyper IgM Syndrome and Normal CD40 Ligand

\begin{tabular}{|c|c|c|c|c|c|}
\hline \multirow{2}{*}{$\begin{array}{l}\text { Patient } \\
\text { number }\end{array}$} & \multirow[b]{2}{*}{ Age } & \multirow{2}{*}{$\begin{array}{l}\text { On } \\
\text { gammaglobulin } \\
\text { therapy }\end{array}$} & \multicolumn{2}{|c|}{$\begin{array}{c}\text { Serum } \\
\text { immunoglobulins* }\end{array}$} & \multirow[b]{2}{*}{ IgG } \\
\hline & & & IgM & $\operatorname{Ig} A$ & \\
\hline \multirow[t]{2}{*}{ Patient 1} & $9 \mathrm{mo}$ & No & 100 & $<5$ & 26 \\
\hline & $6 \mathrm{yr}$ & Yes & 2,590 & 19 & 80 \\
\hline \multirow[t]{2}{*}{ Patient 2} & $21 \mathrm{mo}$ & No & 72 & $<10$ & $<10$ \\
\hline & $24 \mathrm{mo}$ & Yes & 886 & $<10$ & 571 \\
\hline \multirow[t]{2}{*}{ Patient 3} & $20 \mathrm{mo}$ & No & 225 & 34 & 196 \\
\hline & $11 \mathrm{yr}$ & Yes & 2,590 & $<8$ & 259 \\
\hline \multirow[t]{2}{*}{ Patient $4^{\ddagger}$} & $10 \mathrm{mo}$ & No & 1,100 & $<12$ & $<200$ \\
\hline & $12 \mathrm{yr}$ & Yes & 480 & $<6$ & 865 \\
\hline \multirow[t]{2}{*}{ Patient $5^{\ddagger}$} & $9 \mathrm{mo}$ & No & 451 & 30 & 45 \\
\hline & $6 \mathrm{yr}$ & Yes & 462 & 56 & 1,240 \\
\hline
\end{tabular}

* Expressed as mg/dl. $\quad{ }^{\ddagger}$ Patients 4 and 5 are maternal half-brothers. 
ligand. Only one of the patients with normal CD40 ligand (Patient 1) had infections with unusual organisms and none had a past history of pneumocystis pneumonia. In contrast, fifteen of 20 patients with defects in CD40 ligand had opportunistic infections, including 9 patients with a history of pneumocystis pneumonia. In the patients with normal CD40 ligand, neutropenia occurred only in the patient with opportunistic infections, whereas neutropenia occurred in 11 of 15 patients with defects in CD40 ligand.

\section{Discussion}

This study demonstrates that $\sim 20 \%$ of males with clinical and laboratory findings indistinguishable from X-linked hyper IgM syndrome do not have abnormal CD40 ligand but instead have defects in CD40-mediated B cell activation. Although T cells from these patients expressed CD40 ligand appropriately, and their B cells responded to IL4 stimulation with up-regulation of CD23 and CD25, activation of B cells with anti-CD40 did not result in the expected enhancement of CD23 and CD25 expression or secretion of IgE. Although patients with defects in CD40 ligand were more likely to have a past history of opportunistic infections or neutropenia and 7 of 13 had similarly affected male relatives, these characteristics were also seen in patients with hyper IgM syndrome and normal CD40 ligand.

Defects at multiple points along the CD40 signal transduction pathway may result in hyper IgM syndrome. The primary defect in the four patients with hyper IgM syndrome and normal CD40 ligand reported in this paper may be variable. However, $B$ cells from all of these patients expressed normal amounts of CD40. On normal B cells, binding of CD40 ligand to CD40 causes a dramatic decrease in intensity of staining with antiCD40 antibodies. It is not yet clear whether this is caused by modulation of CD40 or to blocking, perhaps due to binding of a soluble form of CD40 ligand to CD40. Nevertheless, the decrease in CD40 staining on B cells from CD40 ligand positive patients after $\mathrm{T}$ cell activation can be taken as an indication of normal CD40 ligand-CD40 interaction, suggesting that both CD40 ligand and CD40 molecules in these patients were capable of interaction.

One of the patients included in this study had a family history of hypohidrotic ectodermal dysplasia and hyper IgM syndrome inherited in an X-linked pattern. Preliminary genetic linkage studies on this family and a second family in which two maternal half brothers had hyper IgM syndrome and hypohidrotic ectodermal dysplasia suggested that this combination of findings was not linked to either the gene for CD40 ligand at Xq27 or the gene for ectodermal dysplasia at Xq13 (24). These two families represent a second form of X-linked hyper IgM syndrome. The three other patients with hyper IgM syndrome and normal CD40 ligand did not have clinical findings of ectodermal dysplasia, suggesting that the primary defect was different in these patients.

Immunofluorescent staining of activated $T$ cells with a recombinant CD40 construct successfully discriminated patients with normal CD40 ligand from those with mutations in CD40 ligand in this study. One can conceive of mutations in CD40 ligand that might permit normal binding to the CD40 construct. Recent reports suggest that the CD40 ligand-CD40 interaction may activate $T$ cells as well as B cells (25). If this is the case, there may be mutations in the amino-terminal intracytoplasmic tail of CD40 ligand which could influence $\mathrm{T}$ cell activation.
This type of mutation as well as mutations in some portions of the extracytoplasmic carboxy-terminal end of CD40 ligand might permit normal binding to the CD40 construct but with abnormal functional consequences. Our studies indicate that if these kinds of mutations occur, they are uncommon. Normal binding of the CD40 construct to activated T cells from a patient with hyper IgM syndrome is more likely to be associated with defects at other points in the CD40 ligand-CD40 axis.

Abnormalities in the CD40 ligand-CD40 axis have been reported in patients with common variable immunodeficiency. Farrington et al. (26) showed that activated $T$ cells from 13 of 31 patients with common variable immunodeficiency had decreased transcript for CD40 ligand and decreased surface expression of CD40 ligand as detected with a CD40 construct. Reduced expression of CD40 ligand correlated with low CD4/ CD8 ratios, decreased production of transcript for IL2, and in some patients, decreased expression of the activation marker, CD69. These findings indicate that reduced expression of CD40 ligand in these patients may be due to a more generalized defect in $\mathrm{T}$ cell function, although the gene for CD40 ligand was not sequenced in any of these patients. Two of the patients included in our study had been previously diagnosed as having common variable immunodeficiency because they did not have elevated serum IgM, a history of opportunistic infections or neutropenia. $\mathrm{T}$ cells from both patients had normal expression of the activation marker, CD25, but failed to bind CD40 construct. Both had mutations in the gene for CD40 ligand. The use of a CD40 construct as diagnostic tool will require appropriate controls to verify normal $T$ cell activation.

$\mathrm{B}$ cells from $\mathrm{CBA} / \mathrm{N}$ mice fail to proliferate in response to anti-CD40; however, they do upregulate CD23 expression (27). Similar defects have not been reported in humans. The group that demonstrated reduced expression of CD40 ligand on activated $T$ cells from some patients with common variable immunodeficiency reported normal B cell proliferation and IgE production in response to ILA and anti-CD40 stimulation in 22 patients with this disorder (28). Although B cells from all four of our patients with hyper IgM syndrome and normal CD40 ligand demonstrated measurable production of $\operatorname{IgE}$ in response to anti-CD40 stimulation, these responses were always $<5 \%$ of the control cultures analyzed in parallel. By contrast, upregulation of $\mathrm{CD} 23$ expression in response to $\mathrm{IL} 4$ stimulation was normal or increased in the three patients studied, suggesting that the decreased response to anti-CD40 was not due to a generalized $B$ cell insensitivity to activation signals.

The identification of CD40 ligand as the defective gene in $\mathrm{X}$-linked hyper IgM syndrome permits better characterization not only of this disorder, but of other disorders that are phenotypically similar. A better understanding of these disorders is a prerequisite for therapeutic interventions such as gene therapy. These studies will also help elucidate normal $\mathrm{T}$ cell-B cell interactions and activation pathways.

\section{Acknowledgments}

We thank Dr. Peter Lane for providing the CD40-Fc construct, Marjorie Fitch-Hilgenberg, Paulina Loo and Randy Valenski for technical assistance and Janice Mann for secretarial assistance.

These studies were supported in part by National Institutes of Health grants AI 25129, CA 58297, and CA 34546; NCI CORE grant P30 CA21765; Crippled Children's Research Foundation of Memphis; and American Lebanese Syrian Associated Charities. 


\section{References}

1. Notarangelo, L. D., M. Duse, and A. G. Ugazio. 1992. Immunodeficiency with hyper-IgM (HIM). Immunodefic. Rev. 3:101-122.

2. Rosen, F. S., J. M. Craig, G. Vawter, and C. A. Janeway. 1968. The dysgammaglobulinemias and X-linked thymic hypoplasia. Birth Defects. 4:6770.

3. Ackerman, B. D. 1964. Dysgammaglobulinemia: report of a case with family history of a congenital gamma globulin disorder. Pediatrics. 34:211-219.

4. Winfield, J. B., P. L. Cohen, L. Bradley, F. D. Finkelman, R. A. Eisenberg, R. Wistar, and J. K. Whisnant. 1982. IgM cryoprecipitation and anti-immunoglobulin activity in dysgammaglobulinemia type I. Clin. Immunol. Immunopathol. 23:58-69.

5. Brahmi, Z., K. H. Lazarus, M. E. Hodes, and R. L. Baehner. 1983. Immunologic studies of three family members with the immunodeficiency with hyperIgM syndrome. J. Clin. Immunol. 3:127-134.

6. Slepian, I. K., S. A. Schwartz, J. J. Weiss, S. L. Roth, and K. P. Mathews 1984. Immunodeficiency with hyper-IgM after systemic lupus erythematosus. $J$. Allergy Clin. Immunol. 73:846-857.

7. Haldane, J. B. S. 1935. The rate of spontaneous mutation of a human gene J. Genet. 31:317-326.

8. Allen, R. C., R. J. Armitage, M. E. Conley, H. Rosenblatt, N. A. Jenkins, N. G. Copeland, M. A. Bedell, S. Edelhoff, C. M. Disteche, D. K. Simoneaux, W. C. Fanslow, J. W. Belmont, and M. K. Spriggs. 1993. CD40 Ligand gene defects responsible for $\mathrm{X}$-linked hyper-IgM syndrome. Science (Wash. DC). 259:990-993.

9. Korthauer, U., D. Graf, H. W. Mages, F. Briere, M. Padayachee, S. Malcolm, A. G. Ugazio, L. D. Notarangelo, R. J. Levinsky, and R. A. Kroczek. 1993. Defective expression of T-cell CD40 ligand causes X-linked immunodeficiency with hyper-IgM. Nature (Lond.). 361:539-541.

10. DiSanto, J. P., J. Y. Bonnefoy, J. F. Gauchat, A. Fischer, and G. de Sain Basile. 1993. CD40 ligand mutations in X-linked immunodeficiency with hyperIgM. Nature (Lond.). 361:541-543.

11. Aruffo, A., M. Farrington, D. Hollenbaugh, X. Li, A. Milatovich, S Nonoyama, J. Bajorath, L. S. Grosmaire, R. Stenkamp, M. Neubauer, R. L. Roberts, R. J. Noelle, J. A. Ledbetter, U. Francke, and H. D. Ochs. 1993. The CD40 ligand, gp39, is defective in activated $\mathrm{T}$ cells from patients with $\mathrm{X}$-linked hyper-IgM Syndrome. Cell. 72:291-300.

12. Ramesh, N., R. Fuleihan, V. Ramesh, S. Lederman, M. J. Yellin, S. Sharma, L. Chess, F. S. Rosen, and R. S. Geha. 1993. Deletions in the ligand for CD40 in X-linked immunoglobulin deficiency with normal or elevated IgM (HIGMX-1). Int. Immunol. 5:769-773.

13. Armitage, R. J., W. C. Fanslow, L. Strockbine, T. A. Sato, K. N. Clifford, B. M. Macduff, D. M. Anderson, S. D. Gimpel, T. Davis-Smith, C. R. Maliszewski, E. A. Clark, C. A. Smith, K. H. Grabstein, D. Cosman, and M. K. Spriggs 1992. Molecular and biological characterization of a murine ligand for CD40. Nature (Lond.). 357:80-82.
14. Hollenbaugh, D., L. S. Grosmaire, C. D. Kullas, N. J. Chalupny, S. Braesch-Andersen, R. J. Noelle, I. Stamenkovic, J. A. Ledbetter, and A. Aruffo. 1992. The human $T$ cell antigen gp39, a member of the TNF gene family, is a ligand for the CD40 receptor: expression of a soluble form of p39 with B cell co-stimulatory activity. EMBO (Eur. Mol. Biol. Organ.) J. 11:4313-4321.

15. Armitage, R. J., T. A. Sato, B. M. Macduff, K. N. Clifford, A. R. Alpert, C. A. Smith, and W. C. Fanslow. 1992. Identification of a source of biologically active CD40 ligand. Eur. J. Immunol. 22:2071-2076.

16. Lane, P., A. Traunecker, S. Hubele, S. Inui, A. Lanzavecchia, and D. Gray. 1992. Activated human T cells express a ligand for the human B cellassociated antigen CD40 which participates in T cell-dependent activation of B lymphocytes. Eur. J. Immunol. 22:2573-2578.

17. Stamenkovic, I., E. A. Clark, and B. Seed. 1989. A B-lymphocyte activation molecule related to the nerve growth factor receptor and induced by cytokines in carcinomas. EMBO (Eur. Mol. Biol. Organ) J. 8:1403-1410.

18. Loenen, W. A. M., L. A. Gravestein, S. Beumer, C. J. M. Melief, A. Hagemeijer, and J. Borst. 1992. Genomic organization and chromosomal localization of the human CD27 gene. J. Immunol. 149:3937-3943.

19. Clark, E. A., and J. A. Ledbetter. 1986. Activation of human B cells mediated through two distinct cell surface differentiation antigens, Bp35 and Bp50. Proc. Natl. Acad. Sci. USA. 83:4494-4498.

20. Liu, Y-J., D. E. Joshua, G. T. Williams, C. A. Smith, J. Gordon, and I. C. M. MacLennan. 1989. Mechanism of antigen-driven selection in germinal centres. Nature (Lond.). 342:929-931.

21. Gruber, M. F., J. M. Bjorndahl, S. Nakamura, and S. M. Fu. 1989. AntiCD45 inhibition of human $B$ cell proliferation depends on the nature of activation signals and the state of B cell activation. J. Immunol. 142:4144-4152.

22. Banchereau, J., P. De Paoli, A. Vallé, E. Garcia, and F. Rousset. 1991 Long-term human B cell lines dependent on interleukin-4 and antibody to CD40. Science (Wash. DC). 251:70-72.

23. Claasen, J. L., A. D. Levine, and R. H. Buckley. 1990. A cell culture system that enhances mononuclear cell IgE synthesis induced by recombinant human interleukin-4. J. Immunol. Methods. 126:213-222.

24. Gault, J., S. Orlow, L. Schneider, R. Fuleihan, B. Pober, M. Jones, M. Litt, and J. Zonana. 1993. Evidence for an X-linked disease locus with a clinical phenotype of hypohidrotic ectodermal dysplasia and immunodeficiency with hyper-IgM; distinct from both the EDA and HIGM1 loci. Cytogenet. Cell Genet. 64:192. (Abstr.)

25. Cayabyab, M., J. H. Phillips, and L. L. Lanier. 1994. CD40 preferentially costimulates activation of CD4+ T lymphocytes. J. Immunol. 152:1523-1531.

26. Farrington, M., L. S. Grosmaire, S. Nonoyama, S. H. Fischer, D. Hollenbaugh, J. A. Ledbetter, R. J. Noelle, A. Aruffo, and H. D. Ochs. 1994. CD40 ligand expression is defective in a subset of patients with common variable immunodeficiency. Proc. Natl. Acad. Sci. USA. 91:1099-1103.

27. Hasbold, J., and G. G. B. Klaus. 1994. B cells from CBA/N mice do not proliferate following ligation of CD40. Eur. J. Immunol. 24:152-157.

28. Nonoyama, S., M. Farrington, H. Ishida, M. Howard, and H. D. Ochs 1993. Activated B cells from patients with common variable immunodeficiency proliferate and synthesize immunoglobulin. J. Clin. Invest. 92:1282-1287. 